\title{
DEVELOPMENT OF THE SYSTEM OF CRITERIA AND \\ INDICATORS OF IMPROVEMENT OF ORGANIZATIONAL CONDITIONS OF THE BALANCED DEVELOPMENT OF THE REGION
}

\section{DESARROLLO DEL SISTEMA DE CRITERIOS E INDICADORES DE MEJORA DE LAS CONDICIONES ORGANIZATIVAS DEL DESARROLLO EQUILIBRADO DE LA REGIÓN}

\author{
Isabella T. Dzagoyeva ${ }^{1}$, Svetlana A. Temmoyeva ${ }^{2}$, Natalya I. Litovka ${ }^{3}$, \\ Rameta E. Shokumova ${ }^{2}$, Béla M. Musayeva ${ }^{4}$ \\ ${ }^{1}$ Doctor of Economics, associate Professor FGBOOU WAUGH "Mountain \\ State Agricultural University" \\ ${ }^{2}$ Candidate of Economic Sciences, associate professor FGBOOU WAUGH \\ "Kabardino-Balkarian state agricultural university of V.M. Kokov" \\ ${ }^{3}$ candidate of physical and mathematical sciences, associate professor \\ FGBOOU WAUGH "Kabardino-Balkarian state agricultural university of \\ V.M. Kokov" \\ ${ }^{4}$ teacher FGBOOU WAUGH "Chechen State University"
}

Enviado: 27 de junio de 2019

Aceptado para publicar: 30 de julio de 2019

Publicado: 8 de agosto de 2019

\begin{abstract}
The complexity of regional socio-ecology-economic systems, their multiaspectness in the conditions of globalization and the increasing competition demands immediate development of theoretic-methodological provisions and practical recommendations for a conclusion of subjects to a positive trajectory of sustainable development that will allow promoting all macroeconomic interests of participants. As the end result of the subsequent coherence of organizational and economic, socio-ecology-economic and other purposes of economic entities of regional economy there has to be a possibility of ensuring the balanced development of territorial subjects of the Russian Federation. The analysis of conditions which limit development of regions or in different directions influence regional economy, allow developing the perspective directions of the successful solution of problems of the balanced development of territories. Similar situation speaks about need of development of the system of criteria and indicators of improvement of organizational conditions of the balanced development of regions.
\end{abstract}

Keywords: globalization, competition, regional economy, management, improvement of organizational conditions, balanced development, system of criteria and indicators.

La complejidad de los sistemas socio-ecológicos-económicos regionales, su respeto múltiple en las condiciones de globalización y la creciente competencia exige el desarrollo inmediato de disposiciones teórico-metodológicas y recomendaciones prácticas para la conclusión de los sujetos a una trayectoria positiva de desarrollo sostenible que permita promover todo intereses macroeconómicos de los participantes. Como resultado final de la coherencia posterior de los propósitos organizativos y económicos, socio-ecológicos-económicos y de otro tipo de las entidades económicas de la economía regional, debe existir la posibilidad de garantizar el desarrollo equilibrado de los sujetos territoriales de la Federación de Rusia.

El análisis de las condiciones que limitan el desarrollo de las regiones o en diferentes direcciones influyen en la economía regional, permiten desarrollar las direcciones de perspectiva de la solución exitosa de los problemas del desarrollo equilibrado de los territorios. Una situación similar habla de la necesidad de desarrollar el sistema de criterios e indicadores de mejora de las condiciones organizacionales del desarrollo equilibrado de las regiones.

Palabras clave: globalización, competencia, economía regional, gestión, mejora de las condiciones organizacionales, desarrollo equilibrado, sistema de criterios e indicadores. 


\section{Introduction}

At statement of problems of the balanced development of the region we mean that, first of all, it is necessary to get rid of subjectivity which is characteristic at adoption of management decisions. It also is the reason for development of reasonable recommendations about improvement of organizational conditions by effective formation of administrative structures of bodies of the state executive power (SEP) and the organization of administrative interactions at implementation of federal and regional target programs.

It is possible to solve a complex of problems of the balanced development of territories only by means of development and involvement by territorial subjects of the Russian Federation of federal and regional target programs and innovative projects which correspond to the budgetary, social, commercial and other requirements. Though, undoubtedly, it is necessary to consider that all this is quite difficult from a methodology position because set of the applied principles, methods and instruments of achievement of the balanced development have quite general, and sometimes even the general dogmatic character.

In practice, especially in the depressive republics of the North Caucasus, there is a disintegration of the purposes of subjects of a regional economic system, even a peculiar opportunism is shown owing to what mesoeconomic proportions are broken, parameters of indicative planning are not observed, tax, contractual and other liabilities are broken.

All this speaks about need of development of effective methods and means of formation of model of the balanced development of the regional economic system allowing opening and describing organizational conditions of effective interaction of various stakeholders of regional development.

\section{Research methodology}

This research is constructed on methodological provisions of works of foreign and Russian scientists on problems of development and use at meso-economic level of the indicative plans, investment projects and other tools and methods directed to the solution of a complex of problems of ensuring the balanced development of the region.

In article system approach, the factorial and functional, comparative and comparative analysis, imitating modeling, forecasting was used.

\section{Research results}

This article sets as its task the possibility of a historical analysis of the novel The Kingdom of the Wicked by A. Burgess, also dating back to the 1980s.

The third novel of the biblical trilogy of Anthony Burgess The Kingdom of the Wicked, like two other works, was the result of work on the screenplay. It was a work on the twelve-hour series Anno Domini, A.D. 1985, delivered by the famous Italian producer Vincenzo Labella, who participated in the creation of the serials Moses the Lawgiver and Jesus of Nazareth. The series A.D. tells of the life and activities of St. Peter in ancient Rome after the crucifixion of Jesus and the emergence of Christianity during the reign of the Roman emperors. As J. Stinson points out, "In the same year (1985) A.D. was originally a telecast, Burgess turned out his The Kingdom of the Wicked, and the novel that wees the fruits of some assiduous research he did for the television movie" [4: 138].

The Kingdom of the Wicked tells of the birth of Christianity after the crucifixion of Jesus Christ, the preaching of the apostles, in particular Paul, the Great Fire in Rome, the persecution of Christians and the destruction of Pompeii, was a kind of continuation of the second part of the biblical trilogy of Anthony Burgess (Man of Nazareth, 1979). But if in the novel Man of Nazareth, to the forefront, Judea is put forward as a kind of provincial space and socio-political issues, represented mainly by the images of the Pharisees and Zealots, then The Kingdom of the Wicked is, first and foremost, the images of Rome and the Roman emperors (Tiberius, Claudius and Nero).

The image of Rome, the problem of the ideal Roman ruler and the socio-political situation of the era, especially interesting Burgess, constitute a significant historical context of the novel The Kingdom of the Wicked. In a conversation with Don Swaim in 1985, the writer confesses: "I was interested in that period" I felt nobody had yet written and heard about it, although we had both sides of the story in the New Testament and we have the Gideon our hotel rooms so we can read about Paul's voyages, but we never read about what was going on in Rome. It's rather like America and Europe: if you sneeze, we catch cold. When Rome sneezed, Israel caught cold" [10: 146].

It is known that Burgess had a significant influence on The King James Version of the Bible (1611), but in the process of research, Anthony Burgess re-read the New Testament in Greek, books on the history of the Roman Empire, since, 
In special literature there was a set of the works devoted to various aspects of the balanced development in recent years. Generally in these works the balanced development of regional economy is analyzed through a prism of budget planning and distribution of budgetary funds.

Really, similar transfer payments in today's realities are the most widespread tool by means of which it is possible to neutralize quite effectively a set of disproportions meso - and macroeconomic development. The sizes and the period of time of the budgetary payments are established by the special federal and regional target strategic documents which are, in general, stabilization programs. [3.8]

According to our scientific hypothesis, we believe that as the most essential to achievement of the balanced development of regional economy one of the most significant and relevant organizational conditions act, as became a subject of our research.

And, we place emphasis on improvement of organizational conditions because they as a basis of structural formation of bodies of GIV were put last century.

Indicative planning is intended for high-quality transformation of public administration, for ensuring mutually agreed actions of government institutions, local governments and business community with an ultimate goal of formation of steady balanced growth and improvement of quality of life of the population.

The principle of an indicativeness and management of regional economy forms creativeness in providing the purpose of regional development by means of solidary development and involvement of GIV by bodies, business and civil institutes of the target program documents focused on realization of the mutually satisfying parameters of the balanced development of regions. [2,8,12]

Implementation of the principle of an indicativeness correlates with the doctrine of indicative planning that allows achieving compliance of parameters of social and economic development of the region to expectations of GIV and other stakeholders of regional development. Feature of indicative planning is that it, being not directive, nevertheless is focused on planning at the state level.

The balanced development of the region happens as a result of a set of multidirectional influences of the developed organizational conditions. All this is of particular importance when determining level of balance of regional development. We believe that only such development which allows providing with identical opportunities for realization of the interests on all participants can be considered as the balanced development. [1.6] At violation of someone's interests (requirements), they are systematized in two groups, depending on gradation of balance:

- Low balanced regional development (it is observed at constant lack of opportunities on one or a number of factors);

- High balanced regional development (total absence of opportunities to satisfy requirements of regional development more, than on one factor).

The end results of monitoring of economic and social situation of the explored region which are presented by group of special economic indicators (gross regional product, industrial output, volumes of investment investments, quality of life, etc.) act as information and analytical base of development of management decisions

According to materials of the state statistical reporting, the depressive republic KabardinoBalkaria practically on all major socio-economic indexes takes $83-85$ places among 85 territorial subjects of the Russian Federation. In recent years there is small growth on a gross regional product $(1.8 \%)$, in agriculture $(22.1 \%)$, the index of industrial growth $(127 \%)$. But it is necessary to recognize that these figures are nominal and there is no growth in the republic. [3]

Speaking about analytics of statistical reporting, it is necessary to recognize that the numerous used indicators, as a rule, are very bulky and laborconsuming that updates need of their modification and selection of the most "digested" indicators.

Researchers recognized that gross domestic product is not so ideal indicator for welfare assessment because it does not allow capturing various processes, different transformations in the environment, and certain phenomena that it is accepted to call "stability" of regional development.

Ideologization of GDP gives contradictory orientation - on the one hand, political leaders focus attention and demand its proliferation, with another, - in the same time all citizens demand not less actively that the government paid more attention to problems of increase in safety, ecological situation, etc. that, in general, can reduce GDP volumes. [4.5]

It should be noted that any federal program document does not do without reflection of the purpose and indicators characterizing transition to something to newer (state).

The analysis of special literature according to various conditions of the balanced development of regions allowed us to mark out the main classification signs and to offer the following modified group of parameters which characterize meso-economic proportions:

A. Economic:

1. economic potential of a regional economic system and its involvement;

2. social;

3. ecological;

4. demographic;

5. resource. 
B. Depending on the level of management:

1. macroeconomic;

2. mesoeconomic;

B. Integrated

G. Indicators of strategy of ecological growth

D. Progressive

E. Investment. [7.11]

The estimated criteria given above (in the form of indicators and coefficients) are quite well painted and intended for characteristic of parameters of mesoeconomic development. At the same time, in the current realities their analysis does not give the chance to gain an objective impression about a trend of structural transformations in the conditions of the balanced development of a regional socio-ecology-economic system.

For the purpose of ensuring objectivity when developing management decisions at the mesolevel with reliable and timely information which allows to characterize quantitatively and qualitatively dynamics of the transformations happening in the region we developed a complex of indicators on the principles formulated in work [11]. They are aimed at analytical diagnostics of organizational conditions of the balanced development of regional economy.

We divide approach at which it is noted that significant differences from an indicator and a vector are characteristic of the indicator in the system of indicative management [11]. Really, the vector shows the direction of development of various social and economic processes, the phenomena; the indicator is the size allowing arguing on the current provision of the studied phenomena, processes.

According to Gelman L.I., the indicator is a peculiar integrated indicator (animator) who is quantitatively determining qualitative parameters of the studied process, provisions. [5]

- Indicators have to correspond to a number of requirements, including:

- $\quad$ to be adequate at reflection of these or those purposes;

- $\quad$ to be exact at quantitative measurements;

- $\quad$ to be objective;

- $\quad$ to be reliable;

- to be unambiguous (identical

understanding);

- $\quad$ to be economic;

- $\quad$ to be comparable;

- $\quad$ to be timely.

The indicator has to allow the analyst to estimate objectively the real situation of a regional socioecology-economic system; to define threshold values of level of social wellbeing, to plan and predict actions for ensuring threshold values; to accept the regulating influences; to estimate activity of the government administrative institutions. [11]

It is difficult to overestimate the importance of indicators and indexes when carrying out effective monitoring, diagnostics and controlling of the balanced development of regional economy. Values of indicators are certain "corridor" of fluctuations for characteristic of dynamics of regional development. At the same time the minimum and maximum index values of controlled parameters need to be considered in the form of threshold values and to involve in quality of final target reference points when developing indicative plans.

Proceeding from need of measurement and assessment of nature of the analyzed processes, under indicators of organizational conditions of the balanced development of regional economy, in the research we understand increment of the socio-ecology-economic, demographic and other indicators counted by an index method. Thus, the carried-out calculations allow demonstrating changes of a socio-ecology-economic situation of the territory which resulted from administrative interactions of structures of management of GIV with various subjects of regional economy aimed at providing the mesoeconomic proportions set during indicative planning. [10]

Indicators have to correspond to a number of requirements, including: to observe coordination of indicators with provisions of normative documents in the corresponding field of activity; to have discretization of indicators; to use, as a rule, quantitative indices or verbal alternative estimates. [7]

The set of indicators is changeable and can be defined according to requirement of assessment of the end results of administrative influences which are directed to forming in the region of investment attractiveness that, finally, will allow economic entities of the territory to implement the own purposes, retaining, at the same time, the common regional interests.

As accord indicators it is possible to consider dynamics of education in regional economy of clusters.

However, it should be noted existence of a number of characteristics of organizational conditions of the balanced development which cannot be evaluated quantitatively, but, nevertheless, which have important gnoseological value. Such situation forces to look for new methodical receptions of the structurally functional analysis for the subsequent monitoring and high-quality interpretation of the end results of activity of administrative structures of bodies of GIV which administrative activity creates organizational conditions of the balanced development of the region.

\section{Conclusions and propositions}

During the research it was succeeded to formulate 
a number of conceptual provisions of the balanced development, in particular, the interrelation between the balanced development and organizational conditions influencing its formation and structures of management of bodies of GIV is established.

The campaign and the principles of selection of the indicators revealing features of organizational conditions of the balanced development of the territory in dynamics are reasonable. In difference from known it is offered to use an index way of calculation.

\section{Conflict of interests}

Authors confirm about no conflict of interest.

\section{References}

Abalkin L.I. Reflections about long-term strategy, science and democracy//economy Questions. - 2006. - No. 12. - Page 6-18

Aloyeva Z.A., Misakov V.S. Development of adaptation crisis response measures in the conditions of the increasing competition//News of the KabardinoBalkarian scientific center RAS. - 2013. No. 6-2 (56). - Page 30-35."

Afashagova S. R., Misakov V.S., Ivanov A.A. Some instruments of stimulation of innovative development of a business environment in the republics of North Caucasus federal district//News of the Kabardino-Balkarian scientific center RAS. - 2014. - No. 5 (61). - Page 75-81.

Blyakhman L. S. Global crisis and paradigm shift of economic development//Messenger St. Petersburg un-that. It is gray.5. - 2013. Issue 2. - Page 3-21 $\begin{aligned} & \text { Gelman L.N. Models of innovative } \\ & \text { processes } \\ & \text { (review of oreign }\end{aligned}$
iterature)//Economy and mathematical
methods. - 2009. - No. 6. - Page 1034-1095

Karmokova H.B., Misakov V.S. Some problems of the organization of the system analysis of a condition of innovative activity//Economic bulletin of the Rostov state university. - 2008. - T. 6. - No. 4-2. Page 85-88.

Lisovtsev L.I. Management of innovative development: Monograph. - Voronezh: AONO VPO "IMMB",2012. - 183 pages.

Misakov V.S., Inalov of B.-A.M., Eskarkhanov L.Ü. Rol and maintenance of a risk management system//Terra Economicus. - 2013. - T. 11. - No. 2-2. - Page 28-32.

Nikitskaya E.V. Indicative management of the innovative capacity of Russia//Transport business of Russia. - 2012. - No. 6. - Page 51-59

Sandu N.S. Problems and strategy of formation of regional innovative systems//Rural economics. - 2013. - No. 10. - Page 2-11

Sirotkina I.V. Indicative management of the industrial enterprises in the innovative environment: theory, methodology, practice. - Voronezh: "Scientific book", 2008. - 187 pages.

Efficiency of activity of regional authorities as factor of strategic development: The monograph / Under the editorship of Lisovtsev L.P. - Voronezh: JSC NO VPO: "IMMB", 2010. - 168. 